\title{
NYELVHASZNÁLATRA NEVELÉS NYELVTANTANÍTÁSSAL
}

\section{Szerző:}

\author{
H. Tóth István (Dr. CSc) \\ Károly Egyetem \\ (Csehország)
}

Szerző e-mail címe:

moszkva228@gmail.com

\section{Lektorok:}

\author{
Nagy Natália (PhD) \\ Ungvári Nemzeti Egyetem \\ (Ukrajna) \\ Mező Ferenc $(\mathrm{PhD})$ \\ Eszterházy Károly Egyetem \\ ...és további két anonim lektor
}

\begin{abstract}
Absztrakt
E tanulmány a nyelvoktatás és -használat fontosságára, problémáira és összefüggéseire összpontosít. Az első rész rávilágít a fiatalok nyelvhasználatának problémáira. A második rész példákat ad a feladatokra, amelyek alkalmazhatók a helyes nyelv használatához.
\end{abstract}

Kulcsszavak: nyelv, nyelvoktatás

Diszciplina: pedagogia

\begin{abstract}
Abstarct
EDUCATION OF THE USE OF LANGUAGE WITH LANGUAGE TEACHING

This study focuses on the importance and problems and relations of language teaching and use. The first part highlights the problems of using the language of the young. The second part gives examples of tasks that can be applied for educating of the correct language using.
\end{abstract}

Keywords: language, language education

Discipline: pedagogy

H. Tóth István (2020): Nyelvhasználatra nevelés nyelvtantanítással. OxIPO - interdiszciplináris tudományos folyóirat, 2020/1, 41-56. doi: 10.35405/OXIPO.2020.1.41 
A pallérozott nyelvhasználatra nevelés alapjának, alfájának és ómegájának a nyelvtan tanításakor a szemlélődő, hozzáadó, haszonelvű, hasznossággal járó nyelv- és irodalompedagógiai stratégia $(\mathrm{H}$. Tóth 2015a) tekinthető.

Tabuk és fétisek szorításában van valami a magyar nyelv óráin. Mivel lehet pontosabbá tennünk a „van valami” szerkezetet? Talán zajlik, folyik valami, illetôleg csinálunk valamit a magyar nyelv óráin. És ez az állapot így van immár sok-sok éve.

tabu: tárgy, élőlény vagy fogalom megemlitésére, vagy érintésére vonatkozó tilalom; sérthetetlenség, szentség.

fétis: valaminek a vallásos tiszteletben, imádatban részesítése.

Ilyen tabu mindenekelőtt a nyelvtan, illetőleg a grammatika tanításának, (vagy éppen: nem tanításának), avagy az úgy csinálunk, mintha tanítanánk dolga. Fétisnek nevezendő példának okáért a kivételek, azaz a kivételnek mondott esetek elemzésének ignorálása vagy elhanyagolása abban a tekintetben, hogy valóban kivételről van-e szó, avagy csupán az egyik fétisről a magyar nyelv óraiak közül; ilyen például a felszólító mód jelének, pontosabban jelváltozatainak a néven nem ne- vezése. Ezeket a példáimat csupán érzékeltető céllal adtam meg, buzdítva másokat is a hasonlók kendőzetlen sorakoztatására. Ne feledjük: a néven nevezés, a probléma számba vétele már egy-egy lépés a probléma feldolgozása érdekében.

Ha hajlandók vagyunk visszatekinteni eleink jótékony szakmai tetteire, akkor fenntartások nélkül kijelenthetjük, hogy az 1970-es években két korszakos jelentőségű tanterv is készült a magyar nyelv tanításához az általános iskolák számára. Az egyik a Zsolnai József nevével fémjelzett Nyelvi-irodalmi és kommunikációs nevelés tananyagterve, amelyik a kommunikációt és a szövegtant állította a középpontba (Zsolnai, 1988). A másikat Takács Etel írta, ez volt a központinak nevezett országos tanterv, ennek lényege a nyelvbasználat alapozása, továbbfejlesztése volt (Takács, 1978).

Később, a rendszerváltást követően az Adamikné Jászó Anna által az ábécétől az érettségiig kidolgozott anyanyelvi nevelés a grammatikát és a retorikát tette meg rendezőelvnek (Adamikné, 2001).

Szinte hihetetlen - napjainkból visszatekintve -, hogy már 1993 tavaszánnyarán elkészült a magyar tantervelmélet és tantervírás első kompetenciaalapú tanterve (Nagy, 1994), amelynek az irodalmi neveléssel összefüggő fejezete elkészíté-sében magam is részt vettem (H. Tóth és Gálosné, 1994).

Minden, amit a magyar nyelv tanításával összefüggésben ezután tantervnek nevez- 
ve írtak, szerkesztettek, lényegében az előzők ilyen-olyan kompilációi voltak, ebből adódóan nélkülöztek minden újszerüséget, ráadásul szürkék és unalmasak lettek. Napjainkra sem javult a helyzet. Akkor mi van ma?

\section{Célkitűzés}

Kibédi Varga Áron Lépések című naplójában ezt olvashatjuk: „Pünkösd a legszebb keresztény ünnep, mert a legabsztraktabb. Nincs semmi romantika - se megható, se tragikus -, ami eltéríthetne a lényegtől, nincs betlehemi istálló, nincs keresztre feszítés. Csak a nyelvek sokasága. Először volt Bábel, a nyelvek szétesése, a büntetés, most pedig pünkösd, a nyelvek felvirágzása, a hitről való soknyelvű beszéd öröme" (Kibédi Varga, 2007).

Mi van most? Bábel, nyelvi zűrzavar? Vagy pünkösd, a nyelvek felvirágzása? Úgy látom, kevés okunk adatik az örvendezésre. Következzék egy vázlatos helyzetkép a nyelvtantanitás védelmében!

\section{Vázlatos helyzetkép}

Kétségtelen, hogy a diákok szóalkotása leleményes, ám az egyhangú szóhasználatukat a durva stílus jellemzi, mert kifejezéseik agresszívak, trágárok fiúk és lányok körében egyaránt. Mindezek után „nem csoda, ha írásaikban a köznyelvi szóalakok helyett is ezeket találjuk, s ők maguk a »keveredést« észre sem veszik, hiszen természetesnek tűnik használatuk számukra" (Laczkó, 2007).

A diáknyelvkutatás friss adatai azt tükrözik, hogy a diákok beszédének új törekvései, jelenségei, kibontakozási irá-nyai és anyanyelvi ismereteiknek a drámai fogyatkozása az íráskészségükre, a helyesírástudásukera bátrányos, káros, sôt kóros hatású. Álljon itt egy rövid leltár a magam adatgyűjtéseiből (H. Tóth, 2007), mások megfigyeléseiből (Hangay, 2007), kutatási eredményeiből (Laczkó, 2007), valamint friss adatmerítéseiből (Nagy, 2018):

a) Jellemző az ékezetek torzítása, elhagyása.

b) Gyakran nem érzékelik az írásjelek általánosan elfogadott szerepét.

c) Az írásjelfajtáik használata sivár, előtérbe kerültek az emotikonok. Írás helyett eligazító, tájékoztató ábrák készítésére alkalmazzák az írásjelkombinációkat, már érettségi dolgozatokban is.

d) Egyre gyakoribbak a rövidítések utáni írásjelek elmaradásai.

e) Általánossá váltak az egybe- és különírási hibák.

f) A fiatalok körében a „csajozós, pasizós dumák", a divatos szóláshasonlatok, kifejezések, az sms-nyelvi adatok nemcsak viszonylagos állandóságot, hanem a szóteremtés vonatkozásában is változásokat mutatnak.

A belyesirási bibák mennyisége és minósége olyan aggasztó mértékben növekedik, hogy ezek elérték már azt a szintet, amely a kommunikációt, tehát a megértést, az 
együttműködést, a kapcsolatot neheritik. Sokszor érezhetjük azt, hogy diákjaink beszédének és írásának a megértéséhez külön szótár szükséges. Mivel nem lehetünk elégedettek a helyesírás-tanítás, illetôleg a helyesírás tudásának jelenlegi állapotával, helyénvaló számba venni a nehézségeket a tisztán látás, a további teendők érdekében.

A helyesírás ügyének sikerét nehezítő, többször akadályozó gondokról is egyenesen kell szólnunk. Ezek a legégetőbb problémák:

a) Az olvasástanítási módszerekkel való kísérletezgetés közben is szem előtt tartandó, hogy a magyar helyesírásban nélkülözhetetlen az értelemtükröző jelleg érvényesítése, mellette, ezzel együtt a szótagolás biztos ismerete.

b) A rendszerszemléletű, a logikus gondolkodást erősítő helyesírás-tanítást kell következetesen érvényesíteni a napjainkban eluralkodott mozaikszemléletű helyesírás-tanítás helyett.

c) A diszlexiával és a diszgráfiával öszszefüggő, nélkülözhetetlen alapismeretekre a társadalmi szükségletek miatt a tanító- és tanárképzésben időés órakeret, gyakorlatias tananyag biztosítandó.

d) Helyesírás-kultúránkat téves beidegződések sora, valamint nyomasztó tájékozatlanság hatja át. Ezek ellen hathatósan a gyakorló pedagógusok és a pedagógusképzés illetékes szakemberei, továbbá a tudományos mûhelyek kutatói léphetnek fel eredmé- nyesen, bizonyítva, hogy a 2015-ben kiadott 12. helyesírási szabályzat az iránymutató, a követendő.

e) Nem segíti a helyesen írás ügyét a társadalmi hozzáállás sem. Gondoljunk arra, hogy a különböző kiírások, utcai, bolti, hivatali feliratok gyakran súlyos hibákat tartalmaznak. A hirdetési újságokban és szórólapokon sok esetben hemzsegnek a primitív helyesírási hibák, de a televíziók felirataiban is rendre találni joggal kifogásolandókat.

f) Durva típushiba a sajtóban, és vészesen terjedő a könyvkiadásban is a helytelen elválasztás.

g) Elfogadhatatlan helyesírási divatok, a magyar írásmódtól idegen, a magyar helyesírás alapjait figyelmen kívül hagyó írásformák zúdulnak ránk naponta az utcáról, a sajtóból, a képernyőkről.

\section{Mi a teendő?}

Hozzá kell járulnunk a helyesírás és a nyelvtan tanítása közötti szerves kapcsolat megerősítéséhez. Tény, hogy sokan vitatják a helyesírás jövőbeni szükségességét. Magam azt a véleményt képviselem, miszerint napjaink magyartanárai közül a helyesírás-tanítás fontosságát hangoztató kollégák nem az utolsó mohikánok. A helyesírás ismeretére és megbízható tudására a holnapokban is szükség lesz, ugyanis ez a tudás szerves része a müveltségnek, a jó modornak és az illemnek is, hogy csak néhányat 
említsek az átlagos embertársunktól elvárható írásbeli kapcsolatteremtés, a kommunikáció komponenseiből. Aki általános és szakmai múveltséggel felvértezettnek tekinti önnönmagát, lehetetlen meglennie nyelvtani ismeretekre épülő megbízható helyesírástudás nélkül.

Nem törödhetünk bele abba a belyzetbe, hogy az elemi iskoláztatástól az egyetemi képrés befejezéséig sem alakul ki általánosságban és egyénenként sem az elfogadható színvonalú helyesen irás keészsége. A helyesírás tanításával összefüggésben mindenekelőtt ezeket az elsődleges anyanyelv-pedagógiai teendő-ket szükséges világosan látnunk:

a) a nyelvtani ismeretek feldolgozása, a nyelvhelyesség csiszolása és a helyesirás gondozása alkossanak szoros kapcsolatot valamennyi magyarórán;

b) a tudatos helyesírás érdekében az állandó gyakorlás elengedhetetlen;

c) diákjaink helyesírási hibatípusait és az ezeket alkotó egyéni hibákat tartsuk számon;

d) mivel a felületesség, a nemtörödömség a helyesirási bibák gyakori okai, ezért meg kell követelnünk tanítványainktól a saját munkájukkal szembeni köteles felelősséget!

Amikor a helyesírás-tanítás kérdéseivel foglalkozunk, akkor természetesen tisztázandók a készségek és képességek fejlesztésének pszichológiai és pedagógiai problémái (Mezō, 2018).
A tudatos tevékenység automatizált komponenseként gondolkodom a készségről, amit utánzással, gyakorlással, alkalmazással lehet megszerezni. A készségek megszerzése nélkülözhetetlen eszköz ahhoz, hogy az ember magasabb rendû szellemi és/vagy egyéb tevékenységeket végezhessen. Az úgynevezett alapkészségeket valamennyi tantárgy tanulásának feltételeiként tartom számon. Ezek közül mindenekelőtt az anyanyelvi készségeket kell megemlítenem, jelesül a beszédkészséget, továbbá az olvasás és az irás technikai szintjét, valamint a helyesírást.

Amikor a képesség tartalmáról és jelentéséről gondolkodom, akkor a személyiségnek azt az egyéni sajátosságát értem, amellyel az ember alkalmassá válik bizonyos cselekvések sikeres végrehajtására, illetőleg meghatározott feladatok eredményes elvégzésére. A helyesírás tanításával kapcsolatban az általános képességek közül a megfigyelóképességet és a problémamegoldó gondolkodást kell előtérbe állítanunk.

A fentiekkel függ össze nyelv- és irodalompedagógiám három sarokpontja ( $\mathrm{H}$. Tóth 2015b): a szemlélódés (kontempláció), a hozzáadás (additivitás) és a haszonelvüség, a hasznosság (funkcionalitás). Amikor a nyelvtant nem önmagáért, hanem a nyelvi jelenségek (a tények, az adatok és az összefüggések) megértéséért, valamint az összefüggéseket további ismeretek és készségek építésére alkalmazzuk, akkor a felfedezés, az elemzés, a vitakultúra, a helyesírás mellett a közlő, tájékoztató és befolyásoló funkciójú szövegezés kompe- 
tenciái erősödnek, ekképpen is segítve a tanulók nyelvi szocializációját.

Vegyük például a szinnevekkel kapcsolatba hozható, a tanítványaink nyelvhasználatát erősítő tevékenységlehetőségeket! Ezekhez a gyakorló pedagógusok, továbbá a tanító- és tanárjelöltek is eredményesen hasznosithatják Bozsik Gabriellának a színnevek helyesírásával összefüggő problémaelemző gondolatait, a színnevek helyesírását segítő, támogató, tanításmódszertani javaslatait (Bozsik, 2018). Jelentős segítséget nyújthat a Szinnevek - szinszótár, ebben 950 olyan címszó van, amelyek színnevek, mellettük 400 címszóban névváltozatok találhatók, valamint 80 címszó árnyalatneveket vonultat fel, továbbá 50 címszó az árnyalatnevek névváltozatait ismerteti (Földvári, 2019.). Mindezen szakirodalmi források mellé illesszük oda A magyar helyesírás szabályai 12. kiadásának kapcsolódó pontjait, példáit. Ezekkel felvértezve kiváló szókincsfejlesztést, eredményes helyesírás-gondozást, hasznos stíluspallérozást végezhetünk a legszükségesebb, immár tanult és alkalmazott nyelvtani szakkifiejezések mozgósitásával, illetőleg ij fogalmak bevezetésével szükség szerint, mindenképpen mértéktartással.

$\mathrm{Ha}$ az eddigiekben a nyelvtanra épitett nyelvhasználat alapozását, erösitését, fejlesztését fejtegettem, akkor miről lehet szó a továbbiakban?

Nyilvánvalóan a magyar helyesírásról. Azért akarok a nélkülöz̧hetetlen háttérismereteket követően újabb és újabb példákat sorakoztatni, hogy még jobban meg tudjam értetni: annak érdekében, hogy kiváló, vagy jó, de legalábbis elfogadható legyen az utánunk jövő generációk nyelvtani elemzéseken alapuló belyesirása, azt éppúgy rendszeresen gyakorolnunk kell, mint az úszást, a futást, a labdarúgást, az éneklést, a kedvenc hangszerünk mindennapi megszólaltatását, a rajzolást és így tovább. Sokan panaszolják, hogy nem látják át a belyesirás-tudomány rendszerét. Segítségül álljon itt ez a nem teljességre törekvố vázlat, majd nyomában az alapozást, a problémafeltárást, az elemzést, a szabályalkotást, a szabálykritikát, a nyelvtani tudatosságra épülő helyesen írást segítő, támogató feladatsorozat.

\section{Nélkülözhetetlen háttérismeretek}

A biztonságos magyar helyesírást az Akadémiai Kiadónál Budapesten 2015ben megjelent $A$ magyar helyesírás szabályai 12. kiadás kötetre alapozzuk, illetőleg onnan merítjük a helyesírással, a helyesen írással összefüggő érveinket, adatainkat. Az ott fellelhető 300 szabályzati pontot most eltekintve az egyes alpontoktól - az itt következő úgynevezett helyesírási alapelvek mentén rendszerezhetjük a könnyebb megértés, a pontosabb átlátás érdekében. Egyébiránt ezek a helyesírási alapelvek jótékonyan segitik helyesirási jártasságunk erösitését, valamint továbbfejlesżtését is.

\section{A kiejtés elve}

A magyar helyesírásban a legfontosabb helyesírási alapelv a kiejtés elve. Ez azt je- 
lenti, hogy az azonos ejtést azonos írásjelekkel, az ejtésbeli különbözőségeket különböző írásjelekkel kell feltüntetnünk. Lényege a hangalak és az értelem tükröztetése, például: koros - kóros - kórós.

\section{A sqóelemzó irásmód}

A sqóelemzó irásmód elvét követjük, amikor a tőhöz járuló toldalék vagy toldalékok elemeit, valamint az összetett szó tagjait világosan, egyértelműen fel-ismerjük, majd írásunkban félreérthetetlenül, nyelvünk értelemtükröztető jellegét előtérbe állítva fel is tüntetjük azokat. Ekkor az íásunkban a magyar nyelv értelemtükröztető jellege kerül a középpontba.

A szóelemzés elve a maga sajátos eszközeivel ad útmutatást a botja, kardjuk, egészség típus mellett a vasgyár, hadsereg, háztető csoportján túl a jegygyürü, kulcscsont, balett-táncos szóalakok helyes írásmódjának az alkalmazására is.

Alaktani ismereteket, elemző készséget és logikus gondolkodást várnak el az anyja, nagyjai, vallja típusúak éppúgy, mint az írásban jelölt teljes hasonulás alcsoportjai, például paddal, bölccsé, mossunk - mossuk, emettôl stb.

\section{A hagyomány elve}

A magyar szókészlet egy bizonyos részének a lejegyzésekor a hagyomány elve ismeretkörhöz igazodunk, hiszen a régebbi korok írásmódjának az emlékét őrizzük bennük. Főbb típusai: a) a régies írású családnevek: Kuun, Raátz, Thewrewk;

b) a $d z$ és a dzs: bodza, dzsungel; peddze, bridzsel-briddzsel;

c) a -j és az -ly: olaj, teljes, kályha, süllyed;

d) a -b végűek: $c$ seh, méh, $s a b$;

e) az - ̈e jelöletlensége: ëszik - eszik;

f) az elemezhetetlen szókövületek: kapzsi, rögtön, mindnyájan stb.

Itt kell szóba hoznunk a jelentésmegkülönböztető céllal írott neveket is, mint: Rác, Rácz̧, Rátæi; Takács, Takách, Takáts stb.

Néhány magyar szóalakban jelentésmegkülönböztető funkciója van a $j-b y$ szembenállásának, így: fogja - foglya, fojt folyt, bojt - bolyt, sója - sólya (a „sólya” szakszó, jelentése: hajócsúsztató vagy csúszda. A Magyar szókincstár szerint hajófelvonó, illetőleg szlip.) stb.

A hagyomány elvével összefüggő írásmód gyakorlásához füzhetjük az ly betű és az $l+y$ betûkapcsolat elemzését. A folyó, gólya stb. szavainkban a $j$ hang helyén írásban hagyományosan $y$ betût alkalmazunk. II. Rákóczi Ferenc nevelőapjának a nevében azonban $l+y$ betűk, hangértékük alapján $l+i$ hangok állnak, vagyis Thököly Imre neve: tököli és nem tököj; ugyanez a szemlélet érvényesül a megbecsült nyelvrokonság-kutató, Reguly Antal nevével kapcsolatban is, ô reguli és nem reguj, amiként a kuruc nótáiról elhíresült Thaly Kálmán neve nem taj és nem táj, hanem tali a kiejtésben. 


\section{Az. egyszerüsités elve}

A magyar helyesírásban gyakran előfordul az egyszerüsités elve, ha az egyszerübb írásforma nem megy a megértés rovására.

$\mathrm{Az}$ egyszerűsítés elvével arra törekszünk, hogy elkerüljük a betűelemek felesleges halmozását: toll - tollal (tol-lal), orr orra (or-ra esett), meggy - meggyel (megy-gyel), asszony - asszonnyal (asz-szony-nyal), fogóddz - fogóddzatok (fo-gódz-dza-tok), bridzs - bridzsel (bri-dzsel [mit csinál?]) - briddzsel (bridzs-dzsel [mivel?]).

Szerepet játszik itt az egyszerűsítésen túl a kiejtés és a szóelemzés is, de mindenekelőtt az értelemtükröztetés. Egyértelmű, hogy nem élhetünk az egyszerűsítés elvével akkor, ha bizonytalanná válna a megértés. Ezért nem hagyhatjuk el az összetett szavak előtagjának az utolsó betűjét vagy az utótagjának az első betűjét: nagygyülés, kulcscsont, balett-táncos, sakek-klub, válllap, rossz- sqivü, illetôleg a családnevek és az utónevek utolsó kettőzött mássalhangzójának egyik elemét sem: Gáll-lal, Mannné, Bernadett-tel, Marcell-lel stb.

\section{A jelentés-elkülönités elve}

Abban áll a jelentés-elkülönités elve, hogy az élőszó nem minden esetben, az írott szókép azonban pontosan segíti a jelentés megkülönböztetését.

Lássuk ezeket a példákat tanúságtevésül: ép - épp, nyelvel - nyelvvel, kis - Kiss, erdei ibolya - Erdei Ibolya, mezei viola - Mezei Viola, majoránnal majoranna - Major Anna, bogáncs - Bogáncs (Fekete István egyik regényének a címe, ahol a fôhőst, a hűséges kutyát hívták így.), nebáncsvirág - Ne bánts, Virág!, folyt (a viz) - fojt (a füst), (ez a) bely (kitünó) bej (, de jó itt!).

\section{A tisztelet elve}

Kisebb jelentőségű a tisztelet elve az írásrendszerünkben, mégis érdemes, tanulságos figyelembe vennünk.

Magánlevelezésben elfogadható, helyénvaló az Édesanyám-, Édesapám-féle íráskép, hivatalos beadványban viszont kerülendő az érzelmek ilyenfajta írásbeli kifejezése.

Törekedjünk arra, hogy neveket ne válasszunk el, hiszen sértésnek is hathatnak: Vörös-marty, Kaff-ka, Jó-kai, Kos-suth, Mi bály, Lász-ló, Á-kos, And-riska (a 'Riska' faluhelyen gyakran fejőstehén neve), Tolsz-toj.

Komikusak az ilyen megoldások is: varázs-ló, edzôtá-borban; Domo-kos Mátyás levele, szoci-áldemokrata nézetek, a demokrácia rökkenömentes folytatása, egy vizsgá-lóbizottságot is felkértek, a kislányunk a gyakor-lóóvodába jár; elmentek a gyerme-kecskék sétálni; öszinte szeretetü vallomás, ör-dögjáték ez a darab stb.

Ugyanakkor figyeljünk néhány történelmi családnév helyes elválasztási formájára, például a Ba-tsá-nyi, Bat-thyá-ny, Dessew-ffy, Lo-ránt-ffy, Szé-che-nyi, Thew-rewke és más hasonlókra!

A te-a, fi-ú, fia-i, a-lom, i-gazság formájú elválasztás szükségtelen mind a kézzel való írás, mind a számítógéppel történő szerkesztés alkalmával.

Némelyik magyar szó elválasztásakor nyelvi illemet sértünk, például a sqar-vas, 
orr-szar-vú, szar-kasztikus, csú-fos, kaka-du stb. esetében. Mellőzzük a szükségtelen elválasztással létrehozható nyelvi tiszteletlenséget, mert félreértésre ad okot!

\section{Azidegen nevek irásának elve}

Szokás megemlíteni az idegen nevek irásának elve csoportot is. Ennek lényege abban rejlik, hogy meg kell tanulnunk az adott szavaknak, kifejezéseknek a célnyelvi írásmóddal való rögzítését. Így figyelemmel leszünk az átadó kultúra nyelvihelyesírási sajátosságaira.

Hibátlanul illik leírnunk, például: Versailles, New York, Stockholm, Strasbourg stb. városneveket éppúgy, mint Voltaire, Rousseau, Shakespeare, Goethe, Johann Strauss és mások nevét is.

Érdemes előtérbe helyeznünk az idegen mellékjelekkel ellátott szavakat is, például: Cerný, Gärtner, Mošna, Mosstrand, Muñoz. stb.

\section{Barangolás a helyesírási}

\section{gyakorlófeladatok világában}

Az alábbiakban néhány példa illusztrálja a nyelvtan és a nyelvhasználat fejlesztését célzó jellegzetes feladatokat:
1. Egészítsük ki az 1. táblázatban látható szógyűjteményeket a megfelelő időtartamú magánhangzóval!

2. Egészítsük ki a 2. táblázatban lévő szógyűjteményeket a megfelelő időtartamú mássalhangzóval!

3. Csoportosítsuk a helyesírási alapelvek szerint a következőket! Válasszunk csoportonként és alapelvenként egy-egy szót, majd szerkesszünk velük egy-egy mondatot!

szövegrészlet, mulatságot, opál, Pálffy, gyüjtései, panaszszó, olyan, kellene, Arannyal, váratlanul, otthonába, mélység, gipszszobor

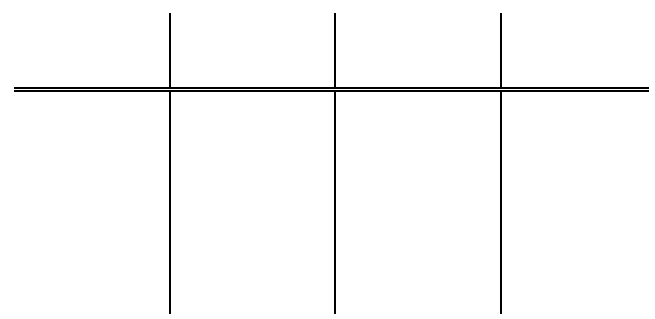

A mondat:

1. táblázat: biányzó (megfelelo" idôtartamú) magánhangzókekal kiegészithetó táblázat (forrás: a Szerző́)

\begin{tabular}{|c|c|c|c|c|}
\hline$o-o ́$ & $\ddot{o}-\ddot{O}$ & $u-u^{\prime}$ & $\ddot{u}-\ddot{u}$ & $\overline{i-i}$ \\
\hline 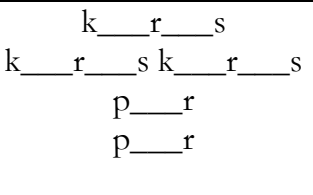 & 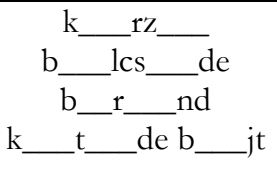 & $\begin{array}{l}\text { bor } \\
\text { alk } \\
\text { sat } \\
\text { gyal } \\
\text { tan }\end{array}$ & 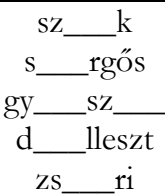 & $\begin{array}{l}\mathrm{h} \_\mathrm{ttük} \\
\mathrm{t} \_ \text {zes, } \\
\text { rogat } \\
\mathrm{s} \text { ma }\end{array}$ \\
\hline
\end{tabular}


2. táblázat: biányzó (megfelelo" idōtartamú) mássalhangzókkeal kiegészithetô" táblázat (forrás: a Szerzó)

\begin{tabular}{|c|c|c|c|c|}
\hline $1-11$ & $r-r r$ & $k-k k$ & $m-m m$ & $\underline{g-g g y}$ \\
\hline $\begin{array}{l}\text { ha_hatatlan } \\
\text { ha_hatatlan } \\
\text { a_egória } \\
\text { tarká_iik } \\
\text { kevese_ }\end{array}$ & 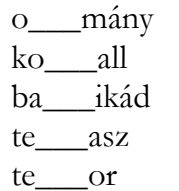 & $\begin{array}{l}\text { bara__ } \\
\text { kaku__ad } \\
\text { a___ad } \\
\text { blo___ } \\
\text { bö__od }\end{array}$ & $\begin{array}{l}\text { e__entáli } \\
\text { marsall } \\
\text { ma__ut } \\
\text { a__ónia } \\
\text { Kle__ Antal }\end{array}$ & $\begin{array}{l}\text { a__ag } \\
\text { fa_ús } \\
\text { me_eslepény } \\
\text { ro_ön_tyút ty }\end{array}$ \\
\hline
\end{tabular}

4. Melyik szükséges: a $j$, avagy a $j j$, az $l y$, esetleg az lly, illetőleg az lj vagy az llj?

a) megi_ed, fo__ton, sompo__og, fésü__!, követe__etek!

b) sa__og, va__on!, hömpö__ög, fák__a, beszé___él!

c) hüve__ku__, he__egy (vonaton), póto__ad, I__és Gyula, ha__ad!

d) indu__unk!, ha__nal, zsiva__og, talá__átok!, bo__ hos

5. Olvassuk el az alábbi meghatározásokat, és válaszoljunk írásban egy-egy szóval!

a) Mindig ezt kiabálja: „Kár, kár!”

b) Ha bosszantani akarják, azt mondják neki, hogy szebb a páva, mint a ...

c) Fehér gyökerű konyhakerti növény.

d) A Tisza is ez, nemcsak a Duna.

e) Ez a virág a szerénység jelképe.

f) A tehén is ez volt kiskorában.

g) Napraforgóból készült zsiradék.

h) A tojásból kikelt madarak testét fedi.

i) Gyermeksapkák dísze.

j) A szoba sarkában állt egykor, és fával, szénnel etették.
6. Karikázzuk be a hibátlanul írt szavakat! Javítsuk ki a hibával közölteket, majd írjuk le őket is szótagolva, hibátlanul!

a) mosoja, haragjuk, tekintéjük, seregéjetek, szabáj, gerej, ünnepéj, imbojog, törköj, papagáj

b) ibolya, szólya, zsivaly, bagoly, lebuly, gallyak, sóhaly, guzsaly, dereglye, erelyük

7. Egészítsük ki a $j$ hang odaillő jelével az alábbi közmondásokat, szólásokat és szóláshasonlatokat! Vitassuk meg társainkkal ezeknek a példáknak a jelentését!

a) Egyszerű, mint a Kolumbusz to__ása.

b) Egy év hí__án egy hete.

c) Hogy a kecske is _óllak__ék, és a káposzta is megmarad__on. 
d) Farkast emlegetnek, mind árt megjelenik.

e) Sok víz lefo__t azóta a Dunán.

f) A hó agot sem fú ák fel egy lélegzettel.

g) Eltűnt, mint a tava___ i hó.

h) Fogadatlan prókátornak a mögött a he e.

i) Ne szól___ szám, nem fá $\mathrm{fe}$ em.

j) A kisu__át sem mozdítja meg.

8. Alkalmazzuk a $j$ hang megfelelő jelét (j, jj, ly, ly)! Az ellenőrzést, majd a javítást követően írjuk le tollbamondásra Szabó Kálmánnak a macskabaglyot bemutató tájékoztató olvasmányát!

\section{Madaraink}

Az élővilág __elentős osztá__át képviselik a madarak. To__ásaikat cser__ék sűrű__ébe, fák ga__ai közé épített fészkeikben he__ezik el. A gó__a, a sirá__, a égmadár fo__ók, tavak madara. A fogo__, a für__, a var__ú, a seregé__ a mezők, a kertek lakó__a. A to__ásrabló sza_kó, a favá__ó harká__, a sárgafe__uß kirá_ka erdőkben él. Néme__ikre éppen a madárfa___ erősebb tag__ai részéről vár nagy veszé___. A ragadozók közül a fülesbago___é__el kel útra, míg a só__om, a karva___ és az ö__ v nappal vadászik. Kese__ű ritkán vetődik Magyarországra.
9. Kapcsoljunk -val, -vel; -vá, -vé ragokat ezekhez a rövidítésekhez, jelekhez a 4. táblázat segítségével!

4. táblázat: -val, -vel, -va, -ve ragok használatának gyakoroltatása (forrás: a Szęró)

\begin{tabular}{|l|l|l|l|}
\hline Példák & $\begin{array}{c}\text {-val, -vel } \\
\text { ragos } \\
\text { példák }\end{array}$ & Példák & $\begin{array}{c}\text {-vá, -vé } \\
\text { ragos } \\
\text { példák }\end{array}$ \\
\hline \hline$\%$ & & $\mathrm{Ft}$ & \\
\hline$d k g$ & & $\$$ & \\
\hline 100 & & $m m$ & \\
\hline$d l$ & & $*$ & \\
\hline 5. & & $k g$ & \\
\hline${ }^{\circ} \mathrm{C}$ & & 3. & \\
\hline
\end{tabular}

10. Töltsük ki a 5. táblázatot az adott példákkal!

5. táblázat: jelek és ragok alkalmazása (a Szerzö)

\begin{tabular}{|c|c|c|c|c|c|}
\hline 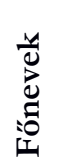 & $\begin{array}{l}\frac{\bar{D}}{n} \\
\frac{0}{0} \\
\frac{0}{0} \\
: 0 \\
1\end{array}$ & 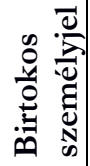 & $\begin{array}{l}\frac{\overline{0}}{4} \\
\frac{0}{0} \\
0\end{array}$ & & $\begin{array}{l}\overline{1} \\
\overline{8} \\
\overline{8}\end{array}$ \\
\hline \multicolumn{6}{|l|}{$d i j$} \\
\hline \multicolumn{6}{|l|}{ bús } \\
\hline \multicolumn{6}{|c|}{ madár } \\
\hline \multicolumn{6}{|l|}{ 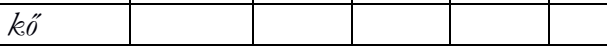 } \\
\hline \multicolumn{6}{|c|}{ darázs } \\
\hline \multicolumn{6}{|l|}{ disz. } \\
\hline \multicolumn{6}{|l|}{ súly } \\
\hline \multicolumn{6}{|l|}{ halom } \\
\hline tür & & & & & \\
\hline
\end{tabular}


11. Írjuk le helyesen a felsorolt tulajdonneveket!
a) andrássy + körút:
b) kodály + körönd:
c) appennini + félsziget:
d) dózsa györgy + tér:
e) velencei + tó:
f) vereckei + hágó:
g) sziget + halma:
h) szerencs + patak:

12. Alkossunk összetett szavakat ezekkel az elemekkel, azután írjunk velük egy-egy alárendelő mondatot a beszélő szándékára is ügyelve! a) csillag vizsgáló, gyermek nevelés, hinta palinta, jön megy, ad vesz, divat lap szerkesztőség, tervező iroda vezető, vadász szenvedély;

b) eszik iszik, földön futó, élen járó, jármű javító, súly pont, tarokk kártya játékos, Kossuth nóta éneklés, sakk készlet gyűjtemény

13. Írjuk a 6. táblázatba a felismert tulajdonnevek helyes alakját! Szedjük az első oszlopban betűrendbe számozással a felismert tulajdonneveket!

6. táblázat: tulajdonnevek helyes alakját és betûrendszerinti sorszámozását gyakoroltató feladat (forrás: a Szerzó)

\begin{tabular}{|c|c|c|}
\hline $\begin{array}{l}\text { Sor- } \\
\text { szám }\end{array}$ & Elemek & Tulajdonnevek \\
\hline & Pilinszky + vers + betanulás & \\
\hline & Kodály + módszer + alkalmazás & \\
\hline & Szent + Ferenc + ima + mondás & \\
\hline & Golf + áramlat + terjedés & \\
\hline & Achilles + ín + szakadás & \\
\hline & Babits + vers + elemzés & \\
\hline & Petôfi + idézet + tudás & \\
\hline & Oscar + díj + átadás & \\
\hline & Ázsia + kutató + találkozó & \\
\hline & Kárpátalja + térkép + rajzolás & \\
\hline & Soós + Kálmán + ösztöndíj & \\
\hline & Szent + István + érdemérem & \\
\hline & Görgey + Artúr + Társaság & \\
\hline & Rákóczi + főiskola & \\
\hline & vérke + parti + sétány & \\
\hline
\end{tabular}


14. Pótoljuk az alábbi mondatokban a hiányzó írásjeleket!

a) S rá te vagy legméltóbb tehát neked adom (Arany János)

b) Nyakatokon vad úri tatárok $\mathrm{S}$ mégis büszke a ti fejetek ( $A d y$ Endre)

c) A magyar nyelv létem jövőm és reményem (Jubász. Ferenc)

d) Leveles dohányát a béres leveszi A gerendáról és a küszöbre teszi Megvágja nagyjábul

S a csizmaszárábul

Pipát húz ki rátölt és lomhán szipákol (Petôfi Sándor)

e) Soha többé nem írok A világ túl öreg és nincs semmi új benne Már mindent leírtak (Jean Nicolas Arthur Rimbaud)

f) Szólhatok az emberek vagy az angyalok nyelvén ha szeretet nincs bennem csak zengő érc vagyok vagy pengő cimbalom (Pál apostol)

g) Uram adj éleslátást a dolgok észlelésére erôt azok megragadására és megtartására képességet és rátermettséget arra hogy ezekhez még mindig hozzá tudjak tanulni Adj tévedhetetlen ítéleteket a számba $A$ helyes beszéd kegyelméért is esdeklek Döntsd el nálam mindig a kezdetet határozd meg előrehaladásom irányát és biztosítsd a vég sikeres és eredményes kimenetelét (Aquinói Szent Tamás) h) A vendéglátás mindig szeretetközösség (Istuán atya)

i) Én csak szegény bűnös vagyok Uram de mihelyt szólítalak kegyelmeddel és irgalmaddal egészen elárasztasz engem. Legnagyobb boldogságomról mondanék le ha nem törekednék arra hogy mindig csodálatos jelenlétedben éljek Ámen (Kolumbusz Kristóf)

15. Egészítsük ki ezt a szöveget a szükséges betűkkel, majd az ellenőrzést és a szükséges javítást követően írjuk le tollbamondás után!

\section{Egy kis séta}

Induljunk sétára udapestnek a agyarország fővárosának, esti oldalán!

A __zabadság__íd közelében találjuk az egykori _özponti_ásárcsarnokot. A ővám_érről továbbmenvén hamarosan a __álvin__érre érkezünk. Innen már megpillanthatjuk a __emzeti__úzeumot. Ebben az épületben volt a __éch__ nyi __önyvtár. Sétáljunk fel a _árba, és tekintsük meg a udai__egység tájait is!

Erre a képzeletbeli sétára _emere _uula írása segítségével indultunk el.

16. Ismerkedjünk közmondásokkal!

a) Pótoljuk a hiányzó betűket ezekből a közmondásdarabokból!

b) Párosítsuk az összetartozó közmondásdarabokat!

c) Írjuk le emlékezetből vagy tollbamondás után a feladatban szereplő közmondásokat! 
1. Az o__an madár ritka,

2. Ami en a mo dó,

3. Megsza__atott erôt

4. Legtová

5. Sok cse

6. Ké szer mérj, a) e___szer vágj!

b) o___an a törülköz

c) a követ is kivá__a.

d) kö__ü elnyomni.

e) az igazsá__al érhetsz!

f) me__nek kedves a kalitka.

\section{Kitekintés}

Az Akadémiai Kiadó 2017-ben figyelemre méltó egynyelvű szótárt jelentetett meg. Ez a Magyar helyesirási szótár, szerkesztője Tóth Etelka, aki $A$ magyar helyesirás szabályai. 12. kiadása szerint állította össze ezt a jelentős terjedelmű szójegyzéket.

A Tinta Könyvkiadó első helyesírási munkafüzetét 2016-ban az új helyesírási szabályzat alapján Fercsik Erzsébet készítette el Helyesirási munkafüzet - Feladatok A magyar helyesírás szabályai 12. kiadásához címmel. A szerző sorra veszi a szabályzat fő pontjait, és ezekhez kínál feladatokat.

Szintén a Tinta Könyvkiadó gondozásában látott napvilágot 2018-ban Cs. Nagy Lajos három tematikus szempontokat alapul vevő munkafüzetegyüttese: $A$ tulajdonnevek helyesírása, az Egybeirás és különírás munkafüret, a Hangjelölési munkafüret.

Ugyancsak a Tinta Könyvkiadónál jelentek meg 2017-18-ban négykötetes sorozatban $H$. Tóth István kompetenciaalapú munkafüzetei: Helyesírási munkafüzet az 5. évfolyam részére, Helyesirási munkafüzet a 6 . évfolyam részére, Helyesírási munkafüzet a 7. évfolyam részére, Helyesirási munkafüzet a 8 . évfolyam részére. Ennek a hét munkafüzet- nek a lelkiismeretes szakmai és anyanyelvi lektora, számos esetben feladatfejlesztője dr. Bozsik Gabriella CSc, az egri Eszterházy Károly Egyetem főiskolai tanára ezúton is illesse köszönet hasznos munkáját!

Reményeink szerint a Tinta Könyvkiadó 2020-ban megjelenteti a középiskolások, illetőleg a középszintú és az emelt szintú érettségire készülők számára Bozsik Gabriella helyesírás-kutató kétkötetes munkafüzetcsomagját, amelyik nyelvtani, nyelvhasználati és általános műveltséget is gondozó tollbamondás-gyűjteményt és a fokozatosság didaktikai elvét következetesen betartó helyesírási feladatgyújteményt is tartalmaz.

Az előzőekben említett szótár, szabályzat, szójegyzék, valamint feladatgyűjtemények és munkafüzetek egyértelműen és körültekintően a nyelvtani tudatosságra neveló, nyelvtani alapozottságú nyelvhasználat-fejlesztést szolgálják kisiskolások, felső tagozatosok és középiskolások esetében egyaránt.

\section{Összegezés}

E tanulmány a kontemplativ (szemlélódó) jellegü, additiv (hozzáadó) szemléletü, funkeci- 
onális (baszonelvü, a hasznosságot támogató) nyelv- és irodalompedagógiai stratégia mentén (H. Tóth 2019) szólt a nyelvtantanitás fontosságáról tabuk és fétisek nélkül, miközben a nyelvhasználat fejlesztésére összpontosító tanítási gyakorlatot állította a középpontba.

Legyen egyértelműen világos minden tanító és magyartanár előtt: nem bölcselkedő nyelvészeket, hanem életvidám, a magyar anyanyelvét boldogan használó és annak értékeire rácsodálkozó általános és középiskolai tanulókat, ifjakat neveljünk kellene nevelnünk.

\section{Irodalom}

Adamikné Jászó Anna (2001): Anyanyelvi nevelés az ábécétöl az érettségïg. Trezor Kiadó, Budapest.

A magyar belyesírás szabályai (2015), tizenkettedik kiadás. Akadémiai Kiadó, Budapest.

Bozsik Gabriella (2018): Gondolatok a színnevek helyesírásának tanításáról. In: Domonkosi Ágnes (szerk.): Tanulmányok a magyar nyelvtudomány köréböl az Eszterházy Károly Egyetem Tudományos Közleményei LXIV. kötet. EKE Líceum Kiadó, Eger. 173-179.

Földvári Melinda (2019): Színnév - színszótár. Letöltés: 2019.11.12. Web: http://www.szintan.hu/

H. Tóth István (2007): Adj esélyt! (Egy helyesírási verseny tényei, adatai néhány megjegyzéssel kísérve). Magyartanítás, Budapest.
H. Tóth István (2015a): Épitkezés a sikerböl és a kudarcból. Additiv szemléletü funkcionális anyanyelvhasználat a kontempláció jegyében. Elhangzott: VIII. Miskolci Taní-tani Konferencia, Miskolci Egyetem Tanárképző Intézete, Miskolc. 2015. január 30.

H. Tóth István (2015b): A kontemplatív alapú, additív szemléletű, funkcionális anyanyelvhasználatot fejlesztő stratégiáról. In: Gazdag Vilmos, Karmacsi Zoltán és Tóth Enikő (szerk.): Értékeek és kibivások II. Autdor-Shark, Ungvár. 211-221.

H. Tóth István (2019): Értékkeresés az óvodai magyar nyelvi nevelésért a hagyományápolás tükrében (Szemlélödés - hozzáadás hasznosság). Sprint Kft. Kiadó, Budapest.

H. Tóth István és Gálosné Szûcs Emília (1994): Irodalmi felkészültség. In: Nagy József (szerk.): Fejlesztési követelmények. Iskolakultúra, 1994, 4. évf. 1-2 szám

Hangay Zoltán (2007): Amit a helyesírási bibák lelepleznek. In: Bozsik Gabriella, Eőry Vilma és V. Raisz Rózsa (szerk.): Hagyomány és ujitás a helyesirásban (Válogatás a Nagy J. Béla országos helyesírási verseny köteteinek anyagából). EKF Liceum Kiadó, Eger.

Kibédi Varga Áron (2007): Lépések (Napló 2005-2006). Kalligram, Pozsony.

Laczkó Mária (2007): Napjaink tizenéveseinek beszéde szóhasználati jellemzők alapján. Magyar Nyelvőr, Budapest. 
Mező Ferenc (2018): Fejlesðtó pedagógia Elmélet és gyakorlati példatár a képességfejlesżtés köréból. $\mathrm{K}+\mathrm{F}$ Stúdió Kft., Debrecen.

Nagy József (szerk.) (1994): Fejlesztési követelmények. Iskolakultúra, 1994, 4. évf. 1-2 szám

Nagy Natália (2018): Az Ukrán-Magyar Oktatási-Tudományos Intézet (UMOTI) diákjainak nyelvhasználati sajátosságai. In: Balázs Géza és Minya Károly (szerk.): Diáknyelv - diákszótár. Egy anyanyelvi pályázat legjobb munkáa
(Válogatás a 2018. évi anyanyelvi pályázat legjobb munkáiból). Anyanyelvápolók Szövetsége - Inter, Budapest.

Takács Etel (1978): Tájékoztató a magyar nyelv és irodalom új tantervéröl (Általános iskola 5-8. osztály). Országos Pedagógiai Intézet, Budapest.

Zsolnai József (1988): A nyelvi, irodalmi és kommunikációs nevelési program tananyagterve (tanterve) az 5-8. osztály számára. Törökbálinti Kísérleti Általános Iskola, Törökbálint-Budapest. 